\title{
Farklı Işık Şiddeti ve Karbondioksit Dozu Uygulamalarının Hidroponik Arpa (Hordeum vulgare L. conv. distichon) Çimi Üzerine Etkileria
}

\author{
Muhammet Karaşahin \\ Necmettin Erbakan Üniversitesi, Mühendislik ve Doğa Bilimleri Fakültesi, Biyosistem Mühendisliği Bölümü, \\ Konya
}

\begin{abstract}
Anahtar kelimeler:
Arpa çimi, hidroponik, ışık

şiddeti, karbondioksit

dozu

Özet. Araştırma farklı ışı şiddeti ve $\mathrm{CO}_{2}$ dozu uygulamalarının hidroponik arpa (Hordeum vulgare L. conv. distichon) çimi üzerine etkilerini belirlemek amacıyla yürütülmüştür. Çalışmada; farklı ışı şiddeti ve karbondioksit dozu uygulamalarının yeşil yem verimi, yeşil yem tohum oranı ${ }^{-1}$, kuru madde oranı ve kaybı, ham protein kazancı, bitki boyu ve kök uzunluğu, ham besin madde içerikleri, hücre duvarı bileşenleri ve metabolik enerji değerleri ile mineral madde içerikleri üzerine etkileri araştırımıştır. Araştırma sonuçlarına göre, farklı ışık şiddeti uygulamalarında en yüksek yeşil yem verimi, yeşil yem tohum oranı-1 ${ }^{-1}$, ham protein kazancı ve bitki boyu, ışı şiddeti I2 ve I3 uygulamalarından elde edilmiştir. Kuru madde oranı ve kuru madde kaybı en fazla I1 uygulamasında olmuştur. Kök uzunluğu bu uygulamadan etkilenmemiştir. Farklı karbondioksit dozu uygulamalarında en yüksek yeşil yem verimi, yeşil yem tohum oranı ${ }^{-1}$, kuru madde kaybı, ham protein kazancı, ham protein, ham kül, ham yağ, metabolik enerji ve azot değerleri kontrol hariç diğer tüm karbondioksit dozu uygulamalarından elde edilmiştir. Kuru madde oranı, bitki boyu ve kök uzunluğu bu

*Sorumlu yazar

mkarasahin@konya.edu.tr uygulamalardan etkilenmemiştir. En yüksek ham selüloz, ADF ve Ca değerleri D1 ve D2 uygulamalarından elde edilmiştir. En yüksek NDF, ADL, P, K, Mg, Fe, $\mathrm{Cu}, \mathrm{Mn}, \mathrm{Zn}$ ve $\mathrm{Na}$ değerleri ise D2 uygulamalarından elde edilmiştir. Yüksek yeşil yem verimi ve ham protein kazançları ile düşük kuru madde kayıplarına sahip hidroponik yeşil arpa yemi üretimi için I2 ve I3 ş̧ık şiddeti uygulamaları ile D1, D2 ve D3 karbondioksit dozları tavsiye edilebilir niteliktedir. Üretim maliyetleri göz önünde bulundurulduğunda 12 ışı şiddeti ile D1 karbondioksit dozu uygulamaları daha önemli hale gelmektedir.
\end{abstract}

\section{The Effects of Different Light Intensity and Carbon Dioxide Dose Treatments on Hydroponic Barley (Hordeum vulgare L. conv. distichon) Grass}

\section{Keywords:}

Barley grass, hydroponic, light intensity, carbon dioxide dose

\begin{abstract}
This research was conducted to determine the effects of different light intensity and $\mathrm{CO}_{2}$ dose treatments on hydroponic barley (Hordeum vulgare L. conv. distichon) grass. In the study were investigated the effects of different light intensity and carbon dioxide dose treatments on green fodder yield and rate, dry matter rate and losses, crude protein gains, plant height, and root lenght, crude nutrient contents, cell wall components, metabolic energy values and mineral elements content. According to the research results, in the different light intensity treatments, the highest green forage yield, crude protein gain, plant height, crude oil, NDF, ADF, metabolic energy and Fe contents, and the lowest dry matter losses were obtained from 12 and 13 treatments, and the highest dry matter rates and losses, crude fiber and $\mathrm{P}$ contents were obtained from $\mathrm{I} 1$ treatment. In the different carbon dioxide dose treatments, the highest green forage yield, crude protein gain, crude nutrient, metabolic energy and $\mathrm{N}$ contents, with the lowest dry matter losses were obtained from D1, D2 and D3 treatments. The highest crude fiber, $A D F$ and $C a$ values were obtained from $D 1$ and $D 2$ treatments. The highest NDF, ADL, P, K, Mg, Fe, Cu, Mn, $\mathrm{Zn}$, and $\mathrm{Na}$ values were obtained from D2 treatment. 12 and 13 light intensity and D1, D2 and D3 carbon dioxide dose treatments can be recommendable in order to produce hydroponic green barley fodder in which having high green fodder yield, crude protein gain and low dry matter losses. When production cost is taken into consideration 12 light intensity and D1 carbon dioxide dose treatments become more important.
\end{abstract}


Karaşahin, Farklı Işık Şiddeti ve Karbondioksit Dozu Uygulamalarının Hidroponik Arpa (Hordeum vulgare L. conv. distichon) Çimi Üzerine Etkileri

\section{GíRiş}

Bitkiler fotosentezle güneşten aldıkları ışık enerjisini glikoz formunda kimyasal enerjiye dönüştürürler. Fotosentez hızını ışık şiddeti, karbondioksit oranı, su ve bitki besin elementleri varlığı, sıcaklık gibi çevre faktörleri ile genetik özellikler etkilemekle beraber en önemli olanları ışık ve karbondioksit miktarıdır (Kajfez-Bogataj 1987; Güneş ve İnal 1995; Vaz et al., 1996; Neri et al., 2003; Cemek ve ark., 2006). Yüksek $\mathrm{CO}_{2}$ dozu aynı zamanda fotorespirasyonu yavaşlattığı için brüt fotosentez miktarı düşük ışık yoğunluğunda bile artmaktadır (Dorais 2003). Atmosferik $\mathrm{CO}_{2}$ seviyesinde fotosentezle elde edilen net karbon kazanımının \%50'si fotorespirasyonla kaybedilebilmektedir (Tolbert et al., 1995). Karbondioksitin bitki gelişimi için önemli bir besin kaynağı olduğu tartışılmaz bir gerçektir. Bu besin kaynağını bitkiler için en uygun düzeyde ortama vermek bitki gelişimini önemli ölçüde arttırmaktadır. Bitki yetiştiriciliğinde amaç bitkilerden alınacak verimi en üst düzeye çıkarmak olduğuna göre karbondioksit gübrelemesi bu amaca hizmet eden etkili yollardan biridir. Birçok araştırmacı yaptıkları çalışmalarında ortamdaki karbondioksit miktarının 1000-1200 ppm dolaylarında olması ile bitki gelişimi ve erkencilik sağlanacağı gibi bitkilerden alınacak verimin üst noktalara çıkabileceği kanısına varmışlardır (Tezcan ve ark., 2011). Karbondioksit gübrelemesinin başarısı, sera içi sıcaklık derecesi ve ışıklanma yoğunluğuna bağlıdır (Sevgican 1989). Bitkilerin genetik yapıları $\mathrm{CO}_{2}$ gübrelemesine farklı tepkilerin verilmesinde etkili olmaktadır (Okay ve Demirtaş 2007).

Hidroponik yeşil arpa çimi üretimi; topraksız yetişme ortamında arpa tanelerinin çimlenme ve gelişimi için gerekli ışık, sıcaklık, su, nem ve besin elementlerinin tedarikinden ibarettir. Bu ortamda 5-8 günde $20-25 \mathrm{~cm}$ boya ulaşan yeşil filiz ve keçe gibi birbirine geçmiş kökler hasat edilerek hayvan yemi olarak kullanılmaktadır. Hidroponik yeşil yem üretimi sürecinde tahıl tanesinde bir dizi kimyasal ve fiziksel değişimler meydana gelmektedir. Tanelerde bulunan enzimlerin hidroliz sonucu aktivasyonu ile protein, karbonhidrat ve yağlar basit bileşiklere ayrılmakta tane ve filizlerde aminoasit, çözünebilen şeker ve yağ asidi miktarlarında artış olmaktadır. Geleneksel yeşil yem üretimi ile hidroponik yeşil yem üretimi kıyaslandığında çok daha küçük alanlarda yıl boyu kesintisiz yeşil yem üretimi, daha zengin lif, protein, vitamin ve mineral içeriği, suyun daha etkin ve verimli kullanımı, içerisindeki çim suyunun hayvanların performanslarında iyileşme sağlaması, tanelerin sindirilebilirliğini artırması gibi özellikleri hidroponik yeşil yem üretiminin dünya genelinde yaygınlaşmasını sağlamaktadır (Dung et al., 2010; Al-Karaki and AlHashimi 2012; Karaşahin 2014).

$\mathrm{Bu}$ çalışma farklı ışık şiddeti ve $\mathrm{CO}_{2}$ dozu uygulamalarının hidroponik arpa (Hordeum vulgare L. conv. distichon) çimi üzerine etkilerini belirlemek amacıyla yürütülmüştür.

\section{MATERYAL VE METOD}

Araştırma, Karabük Üniversitesi Eskipazar Meslek Yüksekokulu Bitkisel ve Hayvansal Üretim Bölümünün $3 \times 3 \times 2.1 \mathrm{~m}$ boyutlarındaki hidroponik yeşil yem üretim odasında 01.02.2015 ile 01.08.2015 tarihleri arasında yürütülmüştür. Çimlendirme kabı olarak $100 \times 10 \mathrm{~cm}$ plastik küvetler kullanılmışır. Araştırmada bitki materyali olarak \% 90 kuru madde ve \% 12.2 ham protein oranına sahip iki sıralı arpa (Hordeum vulgare L. conv. distichon) Tarm-92 çeşidi kullanılmıştır. Tüm uygulamalarda ön ıslatma süresi olarak $24 \mathrm{~h}$, tohum yoğunluğu olarak $2.2 \mathrm{~kg} \mathrm{~m}^{-2}$, ortam sıcaklığı olarak 20 ${ }^{\circ} \mathrm{C}$, ortam nemi olarak \%60, dezenfeksiyon yöntemi olarak ozon, yetiştirme süresi olarak 10 gün, ışıklanma süresi ve rengi olarak $24 \mathrm{~h}$ - sarı ışık (5000 lux), sulama yöntemi, süresi ve sıkığı olarak gelgit, $60 \mathrm{sn} 120 \mathrm{dk}^{-1}$, gübre kaynağı olarak 375 ppm deniz yosunu (Çizelge 1), $\mathrm{CO}_{2}$ dozu olarak 1000 ppm uygulanmıştır. Her uygulamada yalnızca araştırılan parametreler değiştirilmiştir.

Çizelge 1. SeaMax deniz yosunu (Ascophyllum nodosum) özü içeriği.

Table 1. SeaMax seaweed (Ascophyllum nodosum) extract content.

\begin{tabular}{llll}
\hline Özellikler (\%) & & Özellikler (\%) \\
\hline Organik madde & 47.5 & $\mathrm{~S}$ & 2.5 \\
Azot & 0.75 & $\mathrm{Fe}$ & 0.004 \\
Fosfor & 0.02 & $\mathrm{~B}$ & 0.006 \\
Potasyum & 14.9 & $\mathrm{Zn}$ & 0.006 \\
$\mathrm{Ca}$ & 0.3 & $\mathrm{Cu}$ & 0.0002 \\
$\mathrm{Mg}$ & 0.2 & Alginik asit & 5.5 \\
\hline
\end{tabular}

Çalışmada; farklı ş̧ı şiddeti (11; 1000, I2; 5000 ve I3; 10000 lux) ve karbondioksit dozu (K; Kontrol (350 ppm), D1; 1000 ppm, D2; 1500 ppm ve D3; 2000 ppm) uygulamalarının yeşil yem verimi, yeşil yem tohum oranı $^{-1}$, kuru madde oranı ve kaybı, ham protein kazancı, bitki boyu ve kök uzunluğu, ham besin madde (ham protein, kül, yağ ve selüloz) içerikleri, hücre duvarı bileşenleri (NDF, ADF, ADL) ve metabolik enerji değerleri ile küf maya miktarları üzerine etkileri incelenmiştir.

Farklı ışık şiddeti (11, I2 ve I3) uygulamalarında ışık kaynağı olarak $600 \mathrm{~W}$ Osram Plantastar HPS (High 
Karaşahin, Farklı Işık Şiddeti ve Karbondioksit Dozu Uygulamalarının Hidroponik Arpa (Hordeum vulgare L. conv. distichon) Çimi Üzerine Etkileri

Pressure Sodium) lambaları kullanılmıştır. Işık şiddeti ölçümünde TES 1335 marka ışık ölçme cihazı kullanılmıştır. Farklı karbondioksit oranı (K, D1, D2 ve D3) uygulamalarında istenilen $\mathrm{CO}_{2}$ dozunu sağlamak için elektronik sensör ve valf ile kumanda edilen $\mathrm{CO}_{2}$ tüpü ile $1500 \mathrm{~m}^{3} \mathrm{~h}^{-1}$ debili salyangoz fandan yararlanılmıştır. Sulama sisteminde su kaynağı olarak şehir şebekesinden yararlanılmıştır (Çizelge 2).

Çizelge 2. Sulama suyunun bazı kimyasal özellikleri. Table 2. Some chemical properties of irrigation water.

\begin{tabular}{llll} 
Özellikler & \multicolumn{3}{c}{ Özellikler $\left(\mathbf{m g ~ l ~}^{-1}\right)$} \\
\hline $\mathrm{pH}$ & 6.98 & $\mathrm{Zn}$ & 0.94 \\
$\mathrm{EC}\left(\mathrm{mS} \mathrm{cm}^{-1}\right)$ & 0.59 & $\mathrm{P}$ & 0.20 \\
$\mathrm{Ca}\left(\mathrm{mg} \mathrm{|}^{-1}\right)$ & 116.8 & $\mathrm{~K}$ & 0.03 \\
$\mathrm{Mg}\left(\mathrm{mg} \mathrm{l}^{-1}\right)$ & 10.7 & $\mathrm{Mn}$ & 0.02 \\
$\mathrm{Na}\left(\mathrm{mg} \mathrm{l}^{-1}\right)$ & 2.93 & $\mathrm{Cu}$ & 0.02 \\
\hline
\end{tabular}

Yeşil yem ağırlığı tartıldıktan sonra 200'er g örnekler alınarak $105{ }^{\circ} \mathrm{C}$ altında etüvde sabit ağırlığa ulaşıncaya kadar bekletilerek hassas terazide tartılmış elde edilen değerler yeşil yem ağırlığına oranlanarak kuru madde oranları belirlenmiştir. Yeşil yem tohum oranı, yeşil yem kuru madde oranı değerleriyle çarpılmış elde edilen toplam yeşil yem kuru madde yüzdesi ile tohum kuru madde yüzdesi arasındaki farkın tohum kuru madde yüzdesine oranlanmasıyla kuru madde kayıpları hesap edilmiştir. Elde edilen toplam kuru madde miktarı ile ham protein oranı çarpılarak toplam ham protein verimleri hesap edilmiş ve bu değerler tohumun ham protein oranı ile kuru madde miktarı değerleri çarpımı ile oranlanarak ham protein kazançları hesap edilmiştir. Ham kül (AACC 0801), ham protein (AACC 46-12), ham yağ (AACC 30-25) ve ham sellüloz analizleri (AACC 32-10)'a göre dış laboratuvarda yaptırılmış enerji içeriği hesabında aşağıdaki eşitlik 1'den yararlanılmıştır (TSE 2008).

$\mathrm{ME}=3260+[0.455 \times \mathrm{HP} \%]+[3.517 \times \mathrm{HY} \%]-4.037 \times \mathrm{HS} \%]$

\section{Eşitlikte:}

ME: metabolik enerji ( $\left.\mathrm{kcal}^{\mathrm{kg}}{ }^{-1}\right)$, HP: ham protein, HY: ham yağ, HS: ham sellüloz

NDF (Nötr deterjan lif), ADF (Asit deterjan lif) ve ADL (Asit deterjan lignin) analizleri Van Soest ve Robertson (1985)'e göre dış laboratuvarda yaptırılmıştır.

Denemeler tekrarlanan tesadüf parselleri deneme desenine göre 3 tekerrürlü olarak yürütülmüştür. Elde edilen veriler varyans analizine tabi tutularak $F$ testi yapılmak suretiyle farklılıkları tespit edilen işlemlerin ortalama değerleri "Tukey-Kramer HSD" önem testine göre gruplandırılmıştır (JMP 2007).

\section{BULGULAR VE TARTIŞMA}

Yeşil Yem Verimi, Yeşil Yem Tohum Orant-1, Kuru Madde Oranı ve Kaybı, Ham Protein Kazancı, Bitki Boyu ve Kök Uzunluğu

Farklı ışık şiddeti uygulamalarının yeşil yem verimi, yeşil yem tohum ${ }^{-1}$ oranı, kuru madde kaybı, ham protein kazancı ve bitki boyu üzerine etkileri istatistiki olarak önemli $(P<0.01, P<0.05)$ olmuştur. Yeşil yem verimi en fazla ışık şiddetinin 12 ve 13 uygulamalarından (sırasıyla, 11.20 ve 11.02 ), en düşük ise I1 uygulamasından (9.75) elde edilmiştir. Benzer durum yeşil yem tohum oranında da en fazla ışık şiddetinin 12 ve 13 uygulamalarında (sırasıyla, 5.09 ve 5.01 ), en düşük ise yine 11 uygulamasında (4.43) olmuştur. Kuru madde oranında ise en fazla 11 uygulamasında (14.86) en düşük ise I3 uygulamasında (13.78 ) söz konusudur. Kuru madde kaybında, ışık şiddeti 11 uygulamasında en fazla (26.9) diğer uygulamalar aynı grupta yer almıştır. Ham protein kazancı en fazla I2 ve I3 uygulamalarında (sırasıyla 9.28 ve 8.65) söz konusudur. Işık şiddetinin bitki boyuna etkisi en fazla 12 (15.5) ışık şiddetinde bulunmuştur. Kök uzunluğu üzerine farklı ışı şiddeti uygulamalarının etkileri istatistiki olarak önemli olmamıştır (Çizelge 3).

Işık yoğunluğu fotosentezi sınırlamaktadır. Işık enerjisi almayan hiçbir hücre fotosentez yapamaz. Temel olarak, fotosentezin belirli bir dalga boyu aralığında yapraklar tarafından yakalanan foton miktarı ile doğrudan orantılı olduğu, ışık enerjisinin spektral dağılımında ve miktarında meydana gelen değişikliğe bağlı olarak, fotosentez hızının ve miktarının değiştiği belirlenmiştir (Uzun ve Demir 2012).

Kontrol grubuna göre farklı karbondioksit dozu uygulamalarının yeşil yem verimi, yeşil yem tohum ${ }^{-1}$ oranı, kuru madde kaybı ve ham protein kazanc üzerine etkileri istatistiki olarak önemli $(P<0.01)$ olmuştur. Karbondioksit dozu, D1, D2 ve D3 uygulamaları yeşil yem verimi (sırasıyla 11.20, 11.17 ve 10.87), yeşil yem tohum oranında (sırasıyla, 5.09, 5.07 ve 4.94), ve ham protein kazancında (sırasıyla 9.28, 10.55 ve 10.16) ile aynı grupta en fazla olurken, kuru madde kaybında tersine bir durum söz konusu olup, en fazla kontrolde (27.10) olmuştur. Karbondioksit uygulamalarının kuru madde oranı, bitki boyu ve kök uzunluğuna etkisi istatistiki olarak önemsiz çıkmıştır. 
Karaşahin, Farklı Işık Şiddeti ve Karbondioksit Dozu Uygulamalarının Hidroponik Arpa (Hordeum vulgare L. conv. distichon) Çimi Üzerine Etkileri

Çizelge 3. Farklı ışı şiddeti ve karbondioksit dozu uygulamalarının yeşil yem verimi, yeşil yem tohum oranı ${ }^{-1}$, kuru madde oranı ve kaybı, ham protein kazancı bitki boyu ve kök uzunluğu üzerine etkileri.

Table 3. The effects of different light intensity and carbon dioxide dose treatments on green fodder yield, green fodder grain ${ }^{-1}$, dry matter ratio and loss, crude protein gain, plant height and root length values.

\begin{tabular}{|c|c|c|c|c|c|c|c|c|}
\hline \multicolumn{2}{|c|}{ Uygulamalar } & $\begin{array}{c}\text { Yeşil Yem } \\
\text { Verimi } \\
\left(\mathbf{k g ~ m}^{-2}\right)\end{array}$ & $\begin{array}{c}\text { Yeşil Yem } \\
\text { Tohum } \\
\text { Oranı-1 }^{-1}\end{array}$ & $\begin{array}{c}\text { Kuru Madde } \\
\text { Oranı } \\
(\%) \\
\end{array}$ & $\begin{array}{c}\text { Kuru Madde } \\
\text { Kaybı } \\
(\%)\end{array}$ & $\begin{array}{c}\text { HP } \\
\text { Kazancı } \\
(\%) \\
\end{array}$ & $\begin{array}{l}\text { Bitki } \\
\text { Boyu } \\
(\mathrm{cm})\end{array}$ & $\begin{array}{c}\text { Kök } \\
\text { Uzunluğu } \\
\text { (cm) }\end{array}$ \\
\hline \multirow{3}{*}{$\begin{array}{c}\text { Işık } \\
\text { Şiddeti }\end{array}$} & I1 & $9.75 b$ & $4.43 b$ & $14.86 a$ & $26.9 a$ & $4.43 b$ & $14.3 b$ & 13.7 \\
\hline & 12 & $11.20 \mathrm{a}$ & $5.09 a$ & $13.58 b$ & $23.2 b$ & $9.28 a$ & $15.5 a$ & 14.5 \\
\hline & 13 & $11.02 \mathrm{a}$ & $5.01 a$ & 13.78ab & $23.3 b$ & $8.65 a$ & $15.3 a b$ & 14.7 \\
\hline \multicolumn{2}{|c|}{ HSD } & $0.57^{\star \star}$ & 0.26 ** & $0.87^{\star}$ & $0.67^{\star \star}$ & $2.67^{\star}$ & $0.80^{*}$ & Ns \\
\hline \multirow{4}{*}{$\begin{array}{c}\mathrm{CO}_{2} \\
\mathrm{Dozu}\end{array}$} & $\mathbf{K}$ & $10.14 b$ & $4.61 b$ & 14.23 & $27.10 a$ & $0.09 \mathrm{~b}$ & 15.0 & 14.3 \\
\hline & D1 & $11.20 \mathrm{a}$ & $5.09 a$ & 13.58 & $23.25 b$ & $9.28 a$ & 15.5 & 14.5 \\
\hline & D2 & $11.17 a$ & $5.07 a$ & 13.64 & $23.12 b$ & $10.55 a$ & 15.6 & 14.7 \\
\hline & D3 & $10.87 a$ & $4.94 a$ & 14.06 & $22.83 b$ & $10.16 a$ & 15.2 & 14.4 \\
\hline \multicolumn{2}{|c|}{ HSD } & $0.42^{* *}$ & $0.19^{* \star}$ & Ns & $0.83^{* *}$ & $2.34^{\star \star}$ & Ns & Ns \\
\hline
\end{tabular}

HP; Ham protein, HSD; Güvenilir önemli fark, *; $\mathrm{P}<0.05$, ** ; $\mathrm{P}<0.01, \mathrm{Ns}$; Önemli değil.

Yüksek $\mathrm{CO}_{2}$ dozu yapraklara nüfuz eden $\mathrm{CO}_{2}$ miktarını artırdığı için yaprak ağırlığını ve brüt fotosentezi artırmaktadır. Sebze serasında $\mathrm{CO}_{2}$ dozu 350 ppm'den 1000 ppm'e çıkarıldığında ışık yoğunluğu $500 \mu \mathrm{mol} \mathrm{m} \mathrm{m}^{-2} \mathrm{~s}^{-1}$ iken \%33, ışık yoğunluğu $1500 \mu \mathrm{mol} \mathrm{m} \mathrm{m}^{-2} \mathrm{~s}^{-1}$ iken ise $\% 43$ fotosentez miktarında artış olmuştur (Dorais 2003).

Arpanın da içerisinde yer aldığı $\mathrm{C}_{3}$ bitkilerinde, $\mathrm{CO}_{2}$ konsantrasyonunun artması hem yaprak hem de bitki örtüsü düzeyinde fotosentez hızında artış sağlar (Lam et al., 2010; Rattanapichai and Klem 2014). $\mathrm{CO}_{2}$ dozunu 350 ppm'den 1000 ppm'e çıkarmakla buğdayın vejetatif aksamında \%25 artış olurken tane veriminde \%33 artış olmuştur. Bu artış karbondioksit dozu artışı ile birlikte fotosentez miktarındaki artışla açıklanmaktadır. Bu dozdan sonraki artışta solunum miktarındaki azalma dominant faktör olarak ortaya çıkmaktadır (Reuveni and Bugbee 1997). Karaşahin (2015), hidroponik buğday (Triticum aestivum L.) çim suyu üretiminde farklı dozda (Kontrol; 350, D1; 750, D2; 1500 ve D3; 2000 ppm) karbondioksit dozu uygulamalarını çim suyu verim ve besin değerleri üzerine etkilerini belirlemek amacıyla yaptığı çalışmada en yüksek bitki, çim ve çim suyu verimleri ile bitki boyu değerlerini D1 uygulamasından elde ettiğini bildirmiştir. Dünya çapında yapılan birçok araştırmada $\mathrm{C}_{3}$ bitkileri karbondioksit bağlama kapasitesi doyuma ulaşıncaya kadar karbondioksit miktarındaki artış Rubisco'nun oksijenaz aktivitesini baskı altına alırken karboksilaz aktivitesini hızlandırmıştır. Karboksilaz aktivitesinin artması ile birlikte elektron taşınımı ve fotosentez oranı artmakta bunun sonucu karbonhidrat üretiminde ve biyokütlede artış olmaktadır (Kimball and Idso1983; Allen and Vara Prasad 2004; Chytyk 2010).

Ham Protein, Kül, Yağ, Selüloz, NDF, ADF, ADL ve Metabolik Enerji Değerleri

Farklı ışık şiddeti uygulamalarına dönük 12 ve 13 uygulamalarında en yüksek ham yağ (sırasıyla 2.48, 2.44), NDF (sırasıyla, 35.42, 35.21), ADF (sırasıyla 20.65, 20.22) ve metabolik enerji (sırasıyla, 32,12 ve 32.12 ) elde edilerek aynı istatistiki grupta (a) yer almışlardır $(P<0.01)$. En yüksek ham selüloz (17.29) 11 uygulamasından elde edilerek farklı istatistiki grupta (a) yer almıştır $(P<0.01)$. Farklı ışı şiddeti uygulamaları ham protein, kül ve $A D L$ değerleri üzerine istatistiki olarak etkili olmamıştır (Çizelge 4).

Farklı karbondioksit dozu uygulamalarında en yüksek ham protein (sırasıyla, 17.37, 17.54 ve 17.41) kül (sırasıyla, 3.07, 3.16 ve 3.25), yağ (sırasıyla, 2.48, 2.55 ve 2.52) ve metabolik enerji değerleri (sırasıyla, 3212, 3212 ve 3212), D1, D2 ve D3 uygulamalarından elde edilerek aynı istatistiki grupta (a) yer almışlardır $(P<0.01)$. En yüksek NDF ve $A D L$ değerleri $D 2$ uygulamasından (sırasıyla 36.69 ve 3.80) elde edilerek farklı istatistiki grupta (a) yer almıştır (sırasıyla $P<0.05$ ve $\mathrm{P}<0.01$ ). Farklı karbondioksit dozu uygulamaları ham selüloz ve ADF değerleri üzerine istatistiki olarak önemli $(P<0.01)$ olmuş ve en yüksek ham selüloz (sırasıyla 16.02 ve 16.10 ) ve ADF değerleri (sırasıyla, 20.65 ve 21.10) D1 ve D2 uygulamalarından elde edilerek aynı istatistiki grupta (a) yer almışlardır (Çizelge 4). 
Karaşahin, Farklı Işık Şiddeti ve Karbondioksit Dozu Uygulamalarının Hidroponik Arpa (Hordeum vulgare L. conv. distichon) Çimi Üzerine Etkileri

Çizelge 4. Farklı ısık şiddeti ve karbondioksit dozu uygulamalarının ham besin madde içerikleri, hücre duvarı bileşenleri ve metabolik enerji değerleri üzerine etkileri.

Table 4. The effects of different light intensity and carbon dioxide dose treatments on crude nutrient, cell wall components and metabolic energy values.

\begin{tabular}{|c|c|c|c|c|c|c|c|c|c|}
\hline \multicolumn{2}{|c|}{ Uygulamalar } & $\begin{array}{l}\text { HP } \\
\text { (\%) }\end{array}$ & $\begin{array}{l}\text { HK } \\
\text { (\%) }\end{array}$ & $\begin{array}{l}\text { HY } \\
(\%)\end{array}$ & $\begin{array}{l}\text { HS } \\
\text { (\%) }\end{array}$ & $\begin{array}{l}\text { NDF } \\
\text { (\%) }\end{array}$ & $\begin{array}{l}\text { ADF } \\
\text { (\%) }\end{array}$ & $\begin{array}{l}\text { ADL } \\
(\%)\end{array}$ & $\begin{array}{c}\mathrm{ME} \\
\left(\mathrm{Kcal} \mathrm{Kg}^{-1}\right)\end{array}$ \\
\hline \multirow{3}{*}{$\begin{array}{c}\text { Işık } \\
\text { Şiddeti }\end{array}$} & 11 & 17.43 & 2.94 & $2.27 b$ & $17.29 a$ & $29.68 b$ & $11.22 \mathrm{~b}$ & 3.10 & $3206 b$ \\
\hline & 12 & 17.37 & 3.07 & $2.48 a$ & $16.02 b$ & $35.42 a$ & $20.65 a$ & 3.26 & $3212 a$ \\
\hline & 13 & 17.27 & 3.05 & $2.44 a$ & $15.98 b$ & $35.21 a$ & $20.22 a$ & 3.22 & $3212 a$ \\
\hline \multicolumn{2}{|c|}{ HSD } & Ns & Ns & 0.06 ** & $0.52^{\star \star}$ & $1.63^{* *}$ & $0.77^{* \star}$ & Ns & $2.14^{* \star}$ \\
\hline \multirow{4}{*}{$\begin{array}{c}\mathrm{CO}_{2} \\
\text { Dozu }\end{array}$} & $\mathbf{K}$ & $16.75 b$ & $2.81 b$ & $2.13 b$ & $15.82 b$ & $34.15 b$ & $19.20 \mathrm{~b}$ & $3.10 c$ & $3211 b$ \\
\hline & D1 & $17.37 a$ & $3.07 a$ & $2.48 a$ & $16.02 \mathrm{a}$ & 35.42 & $20.65 a$ & $3.26 b c$ & $3212 a$ \\
\hline & D2 & $17.54 a$ & $3.16 a$ & $2.55 a$ & $16.10 \mathrm{a}$ & $36.69 a$ & $21.10 a$ & $3.80 a$ & $3212 a$ \\
\hline & D3 & $17.41 a$ & $3.25 a$ & $2.52 a$ & 15.94 & $34.35 b$ & 119.35 & $3.50 \mathrm{~b}$ & $3212 a$ \\
\hline \multicolumn{2}{|c|}{ HSD } & $0.22^{* *}$ & $0.14^{* *}$ & $0.11^{\text {** }}$ & $0.12^{* *}$ & $1.4^{*}$ & $0.62^{* *}$ & $0.18^{* *}$ & 0.39 ** \\
\hline
\end{tabular}

${ }^{*} ; \mathrm{P}<0.05,{ }^{* *} ; \mathrm{P}<0.01, \mathrm{HSD}$; Güvenilir önemli fark, Ns; Önemli değil.

Çizelge 5. Farklı ı̧ık şiddeti ve karbondioksit dozu uygulamalarının mineral madde içerikleri üzerine etkileri. Table 5. The effects of different light intensity and carbon dioxide dose treatments on mineral matter contents.

\begin{tabular}{|c|c|c|c|c|c|c|c|c|c|c|c|}
\hline \multirow{2}{*}{\multicolumn{2}{|c|}{ Uygulamalar }} & $\mathbf{N}$ & $\mathbf{P}$ & $\mathbf{K}$ & $\mathrm{Ca}$ & Mg & Fe & $\mathrm{Cu}$ & Mn & Zn & $\mathrm{Na}$ \\
\hline & & $\%$ & \multicolumn{9}{|c|}{$\mathrm{mg} \mathrm{kg}^{-1}$} \\
\hline Işık & I1 & 2.79 & $0.87 a$ & 38.69 & 5.39 & 5.97 & $0.24 b$ & 0.21 & $0.22 a$ & $0.36 a$ & 4.55 \\
\hline Şiddeti & 13 & 2.76 & $0.79 b$ & 37.14 & 5.95 & 6.13 & $0.54 a$ & 0.26 & $0.18 b$ & $0.25 b$ & 4.80 \\
\hline HSD & & Ns & $0.05^{\star}$ & Ns & Ns & Ns & $0.02^{* *}$ & Ns & $0.02^{*}$ & $0.04^{\star \star}$ & Ns \\
\hline \multirow{3}{*}{$\begin{array}{c}\mathrm{CO}_{2} \\
\text { Dozu }\end{array}$} & $\mathbf{K}$ & $2.68 b$ & $0.75 b$ & $35.97 b$ & $4.95 b$ & $5.75 c$ & $0.43 c$ & $0.22 c$ & $0.16 \mathrm{~b}$ & $0.20 c$ & $4.15 c$ \\
\hline & D2 & $2.81 a$ & $0.85 a$ & $37.95 a$ & $6.25 a$ & $6.52 a$ & $0.61 a$ & $0.30 a$ & $0.22 a$ & $0.29 a$ & $5.04 a$ \\
\hline & D3 & $2.79 a$ & $0.77 b$ & 36.37ab & $5.15 b$ & $5.95 b c$ & $0.51 b$ & $0.24 b c$ & $0.18 b$ & $0.22 b c$ & $4.37 \mathrm{bc}$ \\
\hline HSD & & $0.03^{* *}$ & $0.05^{\star \star}$ & $1.14^{*}$ & $0.38^{* \star}$ & $0.28^{* *}$ & $0.03^{* *}$ & $0.03^{* \star}$ & $0.03^{* \star}$ & $0.03^{\star \star}$ & $0.43^{* *}$ \\
\hline
\end{tabular}

${ }^{*} ; \mathrm{P}<0.05,{ }^{* *} ; \mathrm{P}<0.01, \mathrm{HSD}$; Güvenilir önemli fark, Ns; Önemli değil.

\section{Mineral Madde İçerikleri}

Farklı ısık şiddeti uygulamalarında en yüksek $P, M n$ ve $\mathrm{Zn}$ miktarları I1 uygulamasından (sırasıyla $0.87,0.22$ ve 0.36) elde edilerek farklı istatistiki grupta (a) yer almışlardır $(P<0.01)$. En yüksek Fe miktarları 12 ve 13 uygulamalarından (sırasıyla 0.56 ve 0.54 ) elde edilerek aynı istatistiki grupta (a) yer almışlardır $(\mathrm{P}<0.01)$. Farklı ışık şiddeti uygulamaları $\mathrm{N}, \mathrm{K}, \mathrm{Ca}, \mathrm{Mg}, \mathrm{Cu}$ ve $\mathrm{Na}$ değerleri üzerine istatistiki olarak etkili olmamıştır (Çizelge 5).

Farklı karbondioksit dozu uygulamalarında en yüksek $\mathrm{N}$ değerleri D1, D2 ve D3 uygulamalarından (sırasıyla 2.78, 2.81 ve 2.79) elde edilerek aynı istatistiki grupta (a) yer almışlardır $(P<0.01)$. En yüksek $P(0.85)$ ve $K$ (37.95) değerleri $D 2$ uygulamasından elde edilerek farklı istatistiki grupta (a) yer almıştır (sırasıyla $P<0.01$ ve $P<0.05$ ). En yüksek Ca değerleri $D 1$ ve $D 2$ uygulamalarından (sırasıyla 5.97 ve 6.25) elde edilerek aynı istatistiki grupta (a) yer almışlardır $(P<0.01)$. En yüksek (0.22) $\mathrm{Mn}$ değerleri $\mathrm{D} 2$ uygulamasından elde edilerek farklı istatistiki grupta (a) yer almıştır $(P<0.01)$.
En yüksek $\mathrm{Mg}, \mathrm{Fe}, \mathrm{Cu}, \mathrm{Zn}$ ve $\mathrm{Na}$ değerleri $\mathrm{D} 2$ uygulamasından (sırasıyla $6.52,0.61,0.30,0.29$ ve 5.04 ) elde edilerek farklı istatistiki grupta (a) yer almıştır $(P<0.01)$. En düşük değerler ise $K$ uygulamasından elde edilmiştir (Çizelge 5).

Hayvanların büyüme, gelişim, üreme, sağlıklı ve ideal vücut fonksiyonları için mineral maddeler hayati önem taşırlar. Mineral madde miktarlarındaki aşırılık ya da eksiklik yem kalitesini olumsuz etkilemekte ve raşitizm, süt humması, yavru atma, halsizlik, iştahsızlık, tetani gibi hastalıklara sebep olmaktadır (Kumar and Soni 2014).

\section{SONUÇ}

Araştırma sonuçlarına göre, farklı ışık şiddeti uygulamalarında en yüksek yeşil yem verimi, yeşil yem tohum oranı ${ }^{-1}$, ham protein kazancı ve bitki boyu, ışık şiddeti I 2 ve 13 uygulamalarından elde edilmiştir. Kuru madde oranı ve kuru madde kaybı en fazla 11 uygulamasında olmuştur. Kök uzunluğu bu 
Karaşahin, Farklı Işık Şiddeti ve Karbondioksit Dozu Uygulamalarının Hidroponik Arpa (Hordeum vulgare L. conv. distichon) Çimi Üzerine Etkileri

uygulamadan etkilenmemiştir. Farklı karbondioksit dozu uygulamalarında en yüksek yeşil yem verimi, yeşil yem tohum oranı ${ }^{-1}$, kuru madde kaybı, ham protein kazancl, ham protein, ham kül, ham yağ, metabolik enerji ve azot değerleri kontrol hariç diğer tüm karbondioksit dozu uygulamalarından elde edilmiştir. Kuru madde oranı, bitki boyu ve kök uzunluğu bu uygulamalardan etkilenmemiştir. En yüksek ham selüloz, ADF ve $C a$ değerleri D1 ve D2 uygulamalarından elde edilmiştir. En yüksek NDF, ADL, $\mathrm{P}, \mathrm{K}, \mathrm{Mg}, \mathrm{Fe}, \mathrm{Cu}, \mathrm{Mn}, \mathrm{Zn}$ ve $\mathrm{Na}$ değerleri ise D2 uygulamalarından elde edilmiştir. Yüksek yeşil yem verimi ve ham protein kazançları ile düşük kuru madde kayıplarına sahip hidroponik yeşil arpa yemi üretimi için 12 ve 13 ışık şiddeti uygulamaları ile D1, D2 ve D3 karbondioksit dozları tavsiye edilebilir niteliktedir. Üretim maliyetleri göz önünde bulundurulduğunda 12 ışık şiddeti ile D1 karbondioksit dozu uygulamaları daha önemli hale gelmektedir.

\section{KAYNAKLAR}

Allen HL and Vara Prasad PV., 2004. Crop responses to elevated carbon dioxide. Encyclopedia of Plant and Crop Science, (Eds. RM. Goodman), Marcel Dekker, pp. 346348.

Al-Karaki G and Al-Hashimi M., 2012. Green fodder production and water use efficiency of some forage crops under hydroponic conditions. ISRN Agronomy, 10: $1-5$.

AOAC., 1990. Association of Official Analytical Chemists Official Method of Analysis, $15^{\text {th }}$ ed, pp. 66-88. Washington, DC, USA.

Cemek B., Karaman S ve Ünlükara A., 2006. Tokat yöresinde seraların iklimlendirme gereksinimleri. Gaziosmanpaşa Üniversitesi Ziraat Fakültesi Dergisi, 23(1): 25-36.

Chytyk CJ., 2010. Leaf photosynthesis in wheat (Triticum spp.) under conditions of low temperature and $\mathrm{CO}_{2}$ enrichment. A Thesis Master of Science, University of Saskatchewan Department of Biochemistry, Saskatoon.

Dorais M., 2003. The use of supplemental lighting for vegetable crop production: Light intensity, crop response, nutrition, crop management, cultural practices. Canadian Greenhouse Conference October 9, Canada.

Dung DD., Godwin IR and Nolan JV., 2010. Nutrient content and in sacco digestibility of barley grain and sprouted barley. Journal Animal and Veterinary Advances, 9: 24852492.

Güneş A ve İnal A., 1995. Farklı ışıklanma sürelerinde yetiştirilen buğday (Triticum aestium L.)'ın verim ve klorofil kapsamına yapraktan uygulanan glikozun etkisi. Pamukkale Üniversitesi Mühendislik Bilimleri Dergisi, 1(1): 69-72.
JMP., 2007. Statistic and Graphics Guide, Release 7, SAS Institute Inc., Cary, USA.

Kajfez-Bogataj L., 1987. Light and temperature dependence of net photosynthesis for buckwheat. Fagopyrum, 7: 1618.

Kapur B., 2010. Artan $\mathrm{CO}_{2}$ ve küresel iklim değişikliğinin Çukurova bölgesinde buğday verimliliği üzerine etkileri. Doktora Tezi (Basılmamış), Çukurova Üniversitesi Fen Bilimleri Enstitüsü, Adana.

Karaşahin M., 2014. Kaba yem kaynağı olarak hidroponik arpa çimi üretiminde kuru madde ve ham protein verimleri üzerine farklı uygulamaların etkileri. Süleyman Demirel Üniversitesi Ziraat Fakültesi Dergisi, 9(1): 27-33.

Karaşahin M., 2015. Farklı karbondioksit dozlarının hidroponik buğday (Triticum aestivum L.) çim suyunun verim ve besin değerleri üzerine etkileri. Uluslararası Tarım ve Yaban Hayatı Bilimleri Dergisi, 1(2): 57-63.

Kimball BA and Idso SB., 1983. Increasing atmospheric $\mathrm{CO}_{2}$ : Effects on crop yield, water use and climate. Agricultural Water Management, 7: 55-72.

Kumar K and Soni A., 2014. Elemental ratio and their Importance in feed and fodder. International Journal of Pure and Applied Bioscience, 2(3): 154-160.

Lam SK., Norton R., Armstrong R and Chen D., 2010. Effect of Elevated Carbon Dioxide on ${ }^{15} \mathrm{~N}$-Fertilizer Recovery Under Wheat in Australia, 19th World Congress of Soil Science, Soil Solutions for a Changing World. 1-6 August 2010, Brisbane, Australia.

Neri D., Battistelli R and Albertini G., 2003. Effects of low-light Intensity and temperature on photosynthesis and transpiration of Vigna sinensis L. Journal of Fruit and Ornamental Plant Research, 11: 17-24.

Okay D ve Demirtaş Ç., 2007. Bursa koşullarında sıcaklık ve $\mathrm{CO}_{2}$ değişimlerinin mısır bitkisinin verim ve evapotranspirasyon üzerine etkisinin belirlenmesi. Yüzüncü Yıl Üniversitesi Ziraat Fakültesi Tarım Bilimleri Dergisi, 17(2): 81-87.

Penuelas J., Biel C and Estiarte M., 1995. Growth, biomass allocation and phenology responses of pepper to elevated $\mathrm{CO}_{2}$ concentrations and different water and nitrogen supply. Photosynthetica, 31: 91-99.

Rattanapichai W and Klem K., 2014. Interactive effects of elevated $\mathrm{CO}_{2}$ concentration, nitrogen nutrition and uvexclusion on yield, aboveground biomass and root development in winter wheat and spring barley. Mendelnet, 95-100.

Reuveni J and Bugbee B., 1997. Very high $\mathrm{CO}_{2}$ reduces photosynthesis, dark respiration and yield in wheat. Annals of Botany, 80: 539-546.

Sevgican A., 1989. Örtü Altı Sebzeciliği. Tarımsal Araştırmaları Destekleme ve Geliştirme Vakfı Yayın No: 19, Yalova. 
Karaşahin, Farklı Işık Şiddeti ve Karbondioksit Dozu Uygulamalarının Hidroponik Arpa (Hordeum vulgare L. conv. distichon) Çimi Üzerine Etkileri

Tezcan A., Atılgan A ve Öz H., 2011. Seralarda karbondioksit düzeyi, karbondioksit gübrelemesi ve olası etkileri. Süleyman Demirel Üniversitesi Ziraat Fakültesi Dergisi, 6 (1): 44-51.

Tolbert NE., Benkert C and Beckt E., 1995. The oxygen and carbon dioxide compensation points of C3 plants: possible role in regulating atmospheric oxygen. Proceedings of The National Academy of Sciences of The United States of America, 92: 11230-11233.

TSE., 2008. Hayvan Yemleri-Metabolik (çevrilebilir) Enerji Tayini Kimyasal Metot. Standart No. 9610, Ankara, Türkiye.
Uzun B ve Demir V., 2012. Fotosentetik aktif radyasyon (FAR) ölçümlerinde LED ve fotodiyotların kullanımı. Tarım Bilimleri Dergisi, 18: 214-225.

Van Soest P and Robertson JB., 1985. A Laboratory Manual for Animal Science. Cornell University, Ithaca, New York, USA.

Vaz I., Correia J., Fernandes J., Soares M., Guedes P., Teixeira P., Santos S and Freitas V., 1996. Searching the effect of different light on photosynthetic rate of aquatic plants (Elodea sp.). file:///C:/Users/hp/Downloads/ Report_ESGN_DumbledoresArmy\%20(1).pdf. [Access: September 15, 2016]. 